\title{
Diagnóstico imuno-histoquímico e caracterização anatomopatológica de Mycoplasma gallisepticum em galinhas de subsistência ${ }^{1}$
}

\author{
Renata A. Casagrande ${ }^{2,3 *}$, Luiza A. Castro², Veronica M. Rolim², Flademir Wouters ${ }^{2}$, \\ Fabiana M. Boabaid ${ }^{2}$, Suyene O. Souza ${ }^{2}$, Priscila R. Guerra ${ }^{2}$, Sérgio C. Silva ${ }^{2}$ \\ e David Driemeier ${ }^{2}$
}

\begin{abstract}
Casagrande R.A., Castro L.A, Rolim V.M., Wouters F., Boabaid F.M., Souza S.O., Guerra P.R., Silva S.C. \& Driemeier D. 2014. [Immunohistochemical diagnosis and pathological characterization of Mycoplasma gallisepticum in free-range chicken.] Diagnóstico imuno-histoquímico e caracterização anatomopatológica de Mycoplasma gallisepticum em galinhas de subsistência. Pesquisa Veterinária Brasileira 34(2):153-161. Departamento de Patologia Clínica Veterinária, Faculdade de Veterinária, Universidade Federal do Rio Grande do Sul, Avenida Bento Gonçalves 9090, Porto Alegre, RS 91540-000, Brazil. E-mail: davetpat@ufrgs.br

Avian mycoplasmosis is caused by bacteria from the Mycoplasmataceae family. Mycoplasma gallisepticum (MG) is the most pathogenic and economically significant species affecting poultry. The aim of this study was to use the immunohistochemistry technique (IHC) as a diagnostic method for the MG infection in poultry. In this report we described two outbreaks of mycoplasmosis caused by MG in free-range chickens. Clinical signs were characterized by prostration, decreased appetite, difficult breathing, nasal and ocular discharge. Necropsy findings were serous secretion in conjunctiva $(7 / 10)$ and seioses $(4 / 10)$, edema and caseous exudate; air sacs thickened with foam and caseous exudate (6/10); trachea diffusely reddish (4/10); lungs with $0.5 \mathrm{~cm}$ whitish spots $(2 / 10)$; and pericardial sac with fibrin exudate $(2 / 10)$. Histologically was observed a lymphoplasmacytic hyperplastic acute tracheitis (10/10), seiositis (5/5) and conjunctivitis (3/4); fibrinonecrotic bronchopneumonia (5/10); acute fibrinous pericarditis (2/10); and fibrinonecrotic aerosaculitis (1/1). IHC anti-MG stained in the extracellular surface of ciliated brush border and/or in the top of epithelium of trachea (10/10), bronchi (5/10) and sinuses (4/5). In seven out of ten cases it was possible to detect MG by real-time PCR from tracheal swabs. IHC anti-MG used as a diagnostic method showed good correlation with clinical signs, lesions and realtime PCR results.
\end{abstract}

INDEX TERMS: Respiratory disease, birds, Mycoplasma gallisepticum, mycoplasmosis, Mollicutes.

RESUMO.- A micoplasmose aviária é causada por bactérias da família Mycoplasmataceae. Mycoplasma gallisepticum (MG) é a espécie mais patogênica e que tem a maior importância econômica para a produção avícola. Este estudo

\footnotetext{
${ }^{1}$ Recebido em 4 de janeiro de 2014.

Aceito para publicação em 17 de fevereiro de 2014.

${ }^{2}$ Departamento de Patologia Clínica Veterinária, Faculdade de Veterinária, Universidade Federal do Rio Grande do Sul (UFRGS), Av. Bento Gonçalves 9090, Porto Alegre, RS 95320-000, Brasil. *Autor para correspondência: casagrande_vet@yahoo.com.br

${ }^{3}$ Instituto Federal Catarinense, Rodovia SC-283 Km 8, Vila Fragosos, Concórdia, SC 89700-000, Brasil.
}

teve por objetivo utilizar a técnica de imuno-histoquímica (IHQ) como método de diagnóstico da infecção por MG em aves. No presente relato são descritos dois surtos de micoplasmose por MG em galinhas de subsistência. Clinicamente as aves apresentaram prostração, hiporexia, dificuldade respiratória, secreção nasal e ocular. Na necropsia foram observados secreção serosa, edema e deposição de cáseo em conjuntiva $(7 / 10)$ e seios nasais $(4 / 10)$, sacos aéreos espessados com espuma e cáseo $(6 / 10)$; traqueia difusamente avermelhada (4/10); pulmões com pontos esbranquiçados de $0,5 \mathrm{~cm}(2 / 10)$; e saco pericárdico com deposição de fibrina (2/10). No exame histopatológico foram 
evidenciados traqueíte $(10 / 10)$, sinusite $(5 / 5)$ e conjuntivite (3/4) hiperplásica linfoplasmocitária aguda; broncopneumonia fibrinonecrótica (5/10); pericardite fibrinosa aguda (2/10); e aerossaculite fibrinonecrótica (1/1). No exame de IHQ anti-MG foi evidenciada marcação na superfície extracelular dos cílios e/ou topo do epitélio da traqueia (10/10), brônquios (5/10) e seios nasais (4/5). Em sete dos dez casos analisados foi detectada a presença de MG por PCR em tempo real realizado a partir de amostras de suabe traqueal. A técnica de IHQ anti-MG utilizada como método de diagnóstico apresentou boa concordância com os sinais clínicos, as lesões histopatológicas e os resultados de PCR em tempo real.

TERMOS DE INDEXAÇÃO: Doença respiratória, aves, Mycoplasma gallisepticum, micoplasmose, Mollicutes.

\section{INTRODUÇÃO}

A micoplasmose aviária é causada por bactérias da família Mycoplasmataceae e mais de 25 espécies foram isoladas em aves. Mycoplasma gallisepticum (MG), M. synoviae (MS), M. meleagridis (MM) e M. iowae (MI) são consideradas as espécies mais importantes para galinhas e perus, sendo que MG é o mais patogênico (Kleven 2008).

Em galinhas, MG causa a Doença Respiratória Crônica (DRC), caracterizada por tosse, espirros, secreção nasal, sinusite, diminuição do consumo de alimento, diminuição no ganho de peso e na produção de ovos. 0 curso clínico da doença geralmente é longo e os sinais clínicos, muitas vezes, podem ser brandos (Ley 2008). No entanto, casos com alta morbidade e mortalidade, geralmente foram associados a fatores ambientais e a infecções por Escherichia coli, pelo vírus da bronquite infecciosa e da doença de Newcastle. Nesses casos, observa-se principalmente aerossaculite severa e também pneumonia, pericardite e peri-hepatite (Gross 1961, Fabricant \& Levine 1962 1962, Gross 1990, Minharro et al. 2001).

As micoplasmoses estão entre as principais doenças aviárias e fazem parte do Programa Nacional de Sanidade Avícola (PNSA) com vigilância oficial na avicultura comercial. Os estabelecimentos avícolas de linhagens puras, bisavós e avós de galinhas devem ser livres de MG e MS. Já as matrizes devem ser livres de MG e sob vigilância e acompanhamento para MS. De acordo com o PNSA, em estabelecimentos avícolas produtores de ovos comerciais, de frango de corte, de galinhas de subsistência (fundo-de-quintal), de exploração de aves silvestres, ornamentais e exóticas, bem como em incubatórios desses estabelecimentos, devem ser realizados controles eventuais, sem regra de monitoria estabelecida (Brasil 2001).

A ausência de monitoria constante em sistemas de produção de aves com ciclo de vida curto como os frangos de corte, bem como poedeiras, aves de criação extensivas, selvagens e ornamentais, representa uma ameaça à sanidade avícola industrial, uma vez que esses animais podem servir como reservatório de micoplasmas, mantendo-os no meio ambiente (Cookson \& Shivaprasad 1994, Nunoya et al. 1995, Nunoya et al. 1997, Minharro et al. 2001, Buim et al. 2009, Gomes et al. 2010, Machado et al. 2012).
Atualmente, o diagnóstico definitivo de micoplasmose é realizado através da reação em cadeia da polimerase (PCR), uma vez que as espécies de Mycoplasma são de difícil isolamento (Callison et al. 2006, Buim et al. 2009, Jarquin et al. 2009, Raviv \& Kleven 2009). Os exames sorológicos de soroaglutinação em placa (SAR) e o teste imunoenzimático (ELISA) também são frequentemente utilizados no diagnóstico (Ley 2008, Kleven \& Ferguson-Noel 2008). No entanto, muitas vezes, através de um exame sorológico ou de PCR não é possível diferenciar os animais portadores daqueles doentes. Os resultados dos exames sorológicos também podem ser inconsistentes, pois os anticorpos só são detectados depois de uma a três semanas após a infecção (Kleven 1975).

Para que o diagnóstico de micoplasmose seja efetivo, é necessário associar os dados do quadro clínico, das lesões macroscópicas e histopatológicas com a identificação do agente. A utilização da imuno-histoquímica (IHQ) permite verificar se o agente identificado está presente na lesão e esse é considerado um importante teste de diagnóstico post mortem (Nunoya et al. 1995, Nunoya et al. 1997, Radi et al. 2000, Yilmaz et al. 2011, Yilmaz \& Timurkaan 2011).

O objetivo desse estudo foi descrever dois surtos de micoplasmose em galinhas de subsistência utilizando a técnica de IHQ como método de diagnóstico da infecção por MG e correlacionar a mesma com os achados clínicos, anatomopatológicos e PCR em tempo real.

\section{MATERIAL E MÉTODOS}

\section{Seleção das amostras}

Durante o período de janeiro de 2011 a dezembro de 2012 acompanhou-se 10 casos de doença respiratória compatível com micoplasmose em galinhas de subsistência enviadas ao Setor de Patologia Veterinária da Universidade Federal do Rio Grande do Sul (SPV-UFRGS). Durante esse período, buscou-se o mesmo número de aves sem histórico de doença respiratória para serem utilizadas como controles negativos. Realizou-se a busca dos blocos de parafina e, posteriormente, os cortes e coloração pelo método de hematoxilina e eosina (HE) para caracterização histológica das lesões. Dessas aves buscaram-se também fragmentos de traqueia congelados.

Suabes de seiosseios nasais ( $\operatorname{casos} 1,7$ e 8), suabe de saco aéreo e saco pericárdico, bem como fragmento de pulmão (caso 1) foram coletados assepticamente e encaminhadas ao Laboratório de Medicina Veterinária Preventiva da UFRGS. Esses foram submetidos ao cultivo bacteriano aeróbio em meio ágar sangue suplementado com 5\% de sangue de carneiro e ágar MacConkey. As amostras foram incubadas a $37^{\circ} \mathrm{C}$, durante 24-72 horas. Após, realizou-se a identificação bacteriana através da observação macroscópica das colônias, da morfologia microscópica e do perfil bioquímico dos isolados. Os testes bioquímicos empregados foram a detecção das enzimas catalase, verificação da presença de citocromo oxidase, fermentação de carboidratos, produção de urease, hidrólise de gelatina, utilização de citrato e degradação de aminoácidos.

\section{Imuno-histoquímica para Mycoplasma gallisepticum e M. sy- noviae}

Fragmentos em blocos de parafina de traqueia (10/10), pulmões $(10 / 10)$, seios nasais $(5 / 10)$, conjuntiva $(4 / 10)$ e sa- 
cos aéreos (1/10) dos casos e fragmentos de traqueia (10/10), pulmões (10/10), sacos aéreos $(3 / 10)$ e seios nasais $(1 / 10)$ dos controle negativos foram submetidos à IHQ anti-MG e anti-MS conforme descrito por Yilmaz et al. (2011) e Yilmaz \& Timurkaan (2011).

As amostras foram submetidas à IHQ pelo método estreptavidina-biotina ligada à peroxidase. 0 bloqueio da atividade da peroxidase endógena foi realizado com a incubação dos cortes dos tecidos numa solução a $10 \%$ de peróxido de hidrogênio em metanol durante 10 minutos. Para a recuperação antigênica utilizou-se tampão citrato pH 6,0 por quatro ciclos de cinco minutos cada em micro-ondas com potência de $750 \mathrm{~W}$. 0 bloqueio das reações inespecíficas foi feito com Protein block (DakoCytomation ${ }^{\circledR}$ ) por 7 minutos, à temperatura ambiente. Utilizaram-se os anticorpos primários anti-Mycoplasma gallisepticum e anti-M. synoviae policlonais produzidos em coelhos (Weybridge Lab.) na diluição 1:800 em solução salina tamponada com fosfato (PBS). As lâminas foram incubadas em câmara úmida por 2 horas a $37^{\circ} \mathrm{C}$. Após esta etapa, os cortes foram incubados com anticorpo secundário biotinilado ligado a estreptavidina-peroxidase (kit LSAB-HRP, K0690, DakoCytomation $\left.{ }^{\circledR}\right) 20$ minutos cada etapa. 0 cromógeno utilizado para a revelação foi 3-amino-9-etilcarbazol (AEC, K3469, DakoCytomation ${ }^{\circledR}$ ). Para contracorar foi utilizada a hematoxilina de Mayer seguida de montagem em meio aquoso (S1964, DakoCytomation). Como controle positivo foi utilizado um corte histológico de traqueia com lesões histopatológica compatíveis com micoplasmose e PCR positivo para MG, enquanto que para MS utilizou-se corte histológico de traqueia de uma galinha inoculado com o isolado k1968. Controles negativos foram realizados com a substituição do anticorpo primário por PBS. Para excluir a possibilidade de reação cruzada do anticorpo com as diferentes espécies de Mycoplasma, o controle positivo de MG foi incubado com o anticorpo anti-MS, o controle positivo de MS foi incubado com anti-MG e um controle positivo de Mycoplasma hyopneumoniae foi incubado com ambos anticorpos. Para as diferentes intensidades de marcação foram atribuídos os graus de (-) ausência de marcação, $(+)$ intensidade discreta, $(++)$ intensidade moderada e $(+++)$ intensidade acentuada.

\section{Detecção de Mycoplasma gallisepticum e Mycoplasma syno-} viae por PCR em tempo real

A detecção de MG e MS por PCR em tempo real foi feita a partir de suabes de traqueia dos casos identificados e dos controle negativos. Em quatro casos, onde não havia a disponibilidade de suabes de traqueia congelados foram usados fragmentos de traqueia em bloco de parafina.

O DNA total foi extraído e purificado de suabes de traqueia utilizando o kit comercial QIAamp DNA Mini Kit (Qiagen ${ }^{\circledR}$ ) e o DNA de amostras emblocadas em parafina (FFPE) com o kit comercial QIAamp DNA FFPE Tissue Kit (Qiagen ${ }^{\circledR}$ ) de acordo com as instruções do fabricante. Para avaliar a qualidade do DNA extraído e a presença de possíveis inibidores na reação, foram adicionados $2 \mu \mathrm{L} /$ amostra de Xeno (controle interno positivo) no tampão de lise antes da extração. Os DNAs foram recuperados em um volume de eluição de $100 \mu \mathrm{L}$ para as amostras de suabes e $50 \mu \mathrm{L}$ para as amostras FFPE. Foram utilizados $5 \mu \mathrm{L}$ de DNA em cada reação.

Todas as reações de PCR em tempo real foram realizadas em duplicata utilizando as sondas Taqman $^{\circledR}$ e oligonucleotídeos do kit comercial MG/MS Custom assay (Life Technologies ${ }^{\circledR}$ ) e enzimas, dNTPs, ROX, tampões e controle interno positivo (Xeno controle) contidos no kit VetMAX-Plus qPCR Master Mix (Life Technologies $^{\circledR}$ ). PCR em tempo real foi feito no equipamento StepOne Plus (Applied Biosystems ${ }^{\circledR}$ ). Os ciclos de amplificação foram aqueles sugeridos pelo fabricante, a saber: $95^{\circ} \mathrm{C}$ por 10 minutos seguido de 40 ciclos de desnaturação a $95^{\circ} \mathrm{C}$ por 15 segundos e $60{ }^{\circ} \mathrm{C}$ por 45 segundos.

Como controles positivos foram utilizadas as bacterinas comercias Myco-Galli MG-70 (Biovet ${ }^{\circledR}$ ) para M. gallisepticum e Mycovax MS-H $\left(\right.$ Merial $^{\circledR}$ ) para M. synoviae. 0 conteúdo liofilizado de um frasco de cada bacterina contendo 1.000 doses (aproximadamente $10^{7} \mathrm{CCU} /$ dose) foi ressuspendido em $30 \mathrm{~mL}$ de PBS, e uma alíquota de $500 \mu \mathrm{L}$ foi aquecida a $95^{\circ} \mathrm{C}$ por 10 minutos, centrifugada por 2 minutos a $10.000 \mathrm{rpm}$, e $1 \mu \mathrm{L}$ do sobrenadante foi utilizado diretamente na reação. Para a quantificação do número de CCU (color-changing units) em cada amostra, foi realizada uma curva padrão de cada controle positivo nas seguintes diluições: $1: 1,1: 50,1: 100,1: 500,1: 1000,1: 5000$ e 1:10.000. Foram adicionados $2 \mu \mathrm{L}$ do controle Xeno diretamente nas reações controle positivas. As amostras apresentando Ct (ciclo threshold) menor que 40 foram consideradas positivas.

\section{RESULTADOS}

O primeiro surto de micoplasmose ocorreu em abril de 2011 em uma propriedade rural do município de Porto Alegre, RS. 0 produtor havia iniciado a criação de aves para postura a menos de um ano e tinha adquirido 100 pintos de 21 dias, aparentemente saudáveis. Após dois meses, comprou mais seis galinhas com aproximadamente quatro meses de idade. Quinze dias após a aquisição dessas seis aves, as mesmas apresentaram prostração, diminuição no consumo de alimento, dificuldade respiratória, secreção nasal e ocular (Fig.1). Em poucos dias os 100 pintos começaram com os mesmos sinais clínicos e no período de 10 dias, 15 morreram. Além desses animais, havia mais 40 galinhas adultas que não apresentaram problemas. 0 produtor encaminhou uma ave morta e três vivas para necropsia (casos 1-4).

O segundo surto ocorreu em fevereiro de 2012 no município de Pantano Grande, RS. Essa propriedade tinha um plantel de 60 galinhas para postura de ovos e rotineiramente era realizada a compra de novos animais. Nesse período houve o nascimento de pintos clinicamente saudáveis até

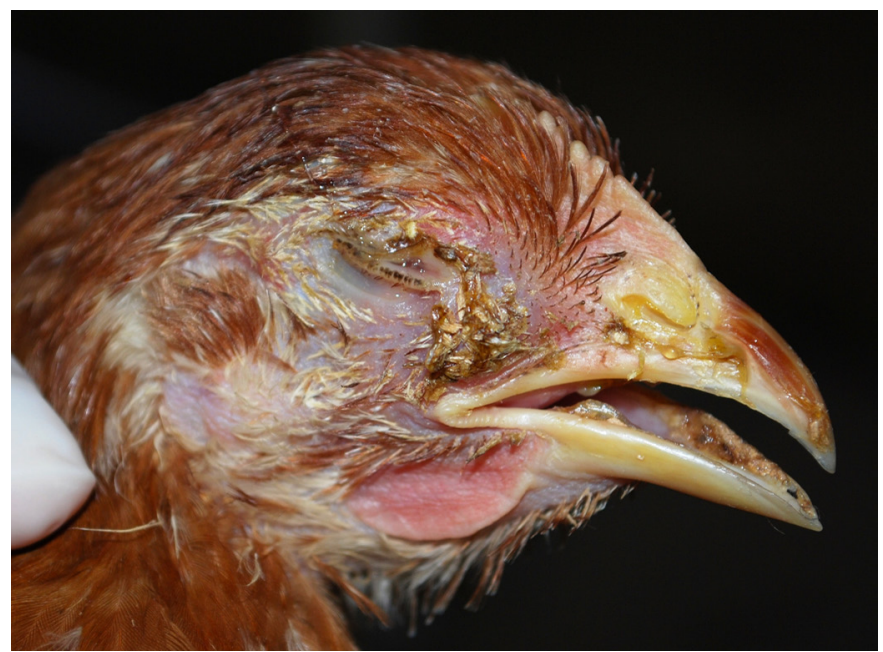

Fig.1. Infecção por Mycoplasma gallisepticum em galinhas. Ave com dificuldade respiratória caracterizada por respiração com bico aberto associado a edema de conjuntiva, secreção serosa ocular e nasal. 
os 30 dias de vida, depois apresentavam prostração, diminuição de consumo de alimento, definhamento e morte. Ao todo morreram 20 pintos. Em visita a propriedade foi observado que muitas aves, com até três meses de idade, também apresentavam dificuldade respiratória, secreção nasal e ocular. Seis aves foram enviadas para necropsia (casos 5-10).

As características das aves acometidas por micoplasmose e dos casos-controle são apresentadas no Quadro 1. Em 10 aves com micoplasmose, nove apresentavam menos de três meses de idade, todas com sinais respiratórios. Entretanto, em quatro estes sinais eram brandos e caracterizados por prostração e leve dificuldade respiratória. As aves utilizadas como controles (11-20) não apresentavam quadro clínico respiratório nem lesões compatíveis com micoplasmose e foram utilizadas como controle para avaliar a especificidade do exame de IHQ para MG e MS.

A caracterização das lesões anatomopatológicas e o resultado de IHQ dos casos de micoplasmose são apre-

Quadro 1. Características das galinhas de subsistência com micoplasmose e dos controles negativos

\begin{tabular}{|c|c|c|c|c|c|c|c|c|c|}
\hline \multirow[t]{2}{*}{ Caso } & \multirow[t]{2}{*}{ Idade } & \multirow[t]{2}{*}{ Diagnóstico } & \multirow[t]{2}{*}{$\begin{array}{l}\text { Quadro clínico } \\
\text { respiratório }\end{array}$} & \multicolumn{2}{|c|}{$\begin{array}{l}\text { Lesão em sistema } \\
\text { respiratório }\end{array}$} & \multirow[t]{2}{*}{$\begin{array}{l}\text { IHQ } \\
\text { MG }\end{array}$} & \multirow[t]{2}{*}{$\begin{array}{l}\text { PCR MG } \\
\text { (CCU) }\end{array}$} & \multirow[t]{2}{*}{$\begin{array}{l}\text { IHQ } \\
\text { MS }\end{array}$} & \multirow[t]{2}{*}{$\begin{array}{c}\text { PCR MS } \\
\text { (CCU) }\end{array}$} \\
\hline & & & & Macrosc. & Histol. & & & & \\
\hline 1 & 80 dias & Micoplasmose & + & + & + & + & $-*$ & - & - \\
\hline 2 & 80 dias & Micoplasmose & + & + & + & + & $9,2 \times 10^{3 *}$ & - & - \\
\hline 3 & 80 dias & Micoplasmose & + & + & + & + & $1,6 \times 10^{6}$ & - & - \\
\hline 4 & 80 dias & Micoplasmose & + & + & + & + & $9,6 \times 10^{1}$ & - & - \\
\hline 5 & 40 dias & Micoplasmose & + & - & + & + & $-*$ & - & - \\
\hline 6 & 40 dias & Micoplasmose & + & + & + & + & $-*$ & - & - \\
\hline 7 & 30 dias & Micoplasmose & + & + & + & + & $1,3 \times 10^{2}$ & - & - \\
\hline 8 & 30 dias & Micoplasmose & + & + & + & + & $3,1 \times 10^{3}$ & - & - \\
\hline 9 & 30 dias & Micoplasmose & + & - & + & + & $3,6 \times 10^{3}$ & - & - \\
\hline 10 & 1 ano & Micoplasmose & + & + & + & + & $2,7 \times 10^{3}$ & - & - \\
\hline 11 & 1 ano & Pasteurelose & - & + & - & - & - & - & $8,7 \times 10^{2}$ \\
\hline 12 & 1 ano & Pasteurelose & - & + & - & - & - & - & - \\
\hline 13 & 1 ano & Pasteurelose & - & + & - & - & $1,2 \times 10^{1}$ & - & $5,2 \times 10^{2}$ \\
\hline 14 & 6 meses & Botulismo & - & - & - & - & 9,3 & - & $1,1 \times 10^{3}$ \\
\hline 15 & 1 ano & Botulismo & - & - & + & - & - & - & - \\
\hline 16 & 1 ano & Botulismo & - & - & + & - & - & - & - \\
\hline 17 & 4 meses & Septicemia & - & - & + & - & - & - & - \\
\hline 18 & NI & Leucose & - & - & - & - & $4,7 \times 10^{1}$ & - & $1,4 \times 10^{3}$ \\
\hline 19 & 1,5 anos & Colibacilose & $\mathrm{NI}$ & - & - & - & - & - & - \\
\hline 20 & 1,5 anos & Colibacilose & NI & - & - & - & - & - & - \\
\hline
\end{tabular}

$\overline{\mathrm{IHQ}}$ = imuno-histoquímica; PCR = reação de polimerase em cadeia; $\mathrm{CCU}=$ color-changing unit; PCR + = CT < 40; MG = Mycoplasma gallisepticum; MS = Mycoplasma synoviae; NI = dado não informado; *PCR de amostras emblocadas em parafina; + = presente ou positivo; - = ausente ou negativo; casos 1 a 4 = primeiro surto; casos 5 ao 10 = segundo surto.

Quadro 2. Caracterização anatomopatológica e imuno-histoquímica dos casos de micoplasmose em galinhas de subsistência

\begin{tabular}{|c|c|c|c|}
\hline Órgãos & $\begin{array}{l}\text { Lesões macroscópicas } \\
\left.\text { ( } \mathrm{n}^{\circ} \text { casos }\right)\end{array}$ & $\begin{array}{l}\text { Lesões histopatológicas } \\
\left.\text { ( } \mathrm{n}^{\circ} \text { casos }\right)\end{array}$ & $\begin{array}{l}\text { IHQ anti-MG } \\
\left(\mathrm{n}^{\circ} \text { casos }\right)\end{array}$ \\
\hline Conjuntiva & $\begin{array}{l}\text { - Secreção serosa }(5 / 10) \\
\text { - Edemaciada e cáseo }(2 / 10)\end{array}$ & $\begin{array}{l}\text { - Conjuntivite hiperplásica linfoplasmocitária } \\
\text { aguda difusa moderada(3/4) }\end{array}$ & $-(4 / 4)$ \\
\hline Seios nasais & $\begin{array}{l}\text { - Secreção serosa }(2 / 10) \\
\text { - Deposição de cáseo }(2 / 10)\end{array}$ & $\begin{array}{l}\text { - Seiosite hiperplásica linfoplasmocitária } \\
\text { aguda difusa moderada }(5 / 5)\end{array}$ & $\begin{array}{c}-(1 / 5) \\
++(3 / 5) \\
+++(1 / 5)\end{array}$ \\
\hline Traqueia & $\begin{array}{c}\text { - Difusamente avermelhada } \\
(4 / 10)\end{array}$ & $\begin{array}{l}\text { - Traqueíte hiperplásica linfoplasmocitária } \\
\text { aguda difusa }(10 / 10)\end{array}$ & $\begin{array}{c}+(7 / 10) \\
++(1 / 10) \\
+++(2 / 10)\end{array}$ \\
\hline Pulmões & $\begin{array}{c}\text { - Pontos esbranquiçados de } \\
0,5 \mathrm{~cm}(2 / 10)\end{array}$ & $\begin{array}{l}\text { - Broncopneumonia fibrinonecrótica } \\
\text { multifocal acentuada }(5 / 10) \\
\text { - Hiperplasia epitelial difusa acentuada da } \\
\text { mucosa de brônquios }(3 / 10) \\
\text { - Hiperplasia linfoide peribronquial acentuada } \\
(1 / 10) \text { e moderada }(2 / 10)\end{array}$ & $\begin{array}{c}-(5 / 10) \\
+(4 / 10) \\
++(1 / 10)\end{array}$ \\
\hline Sacos aéreos & $\begin{array}{l}\text { - Deposição de espuma e } \\
\text { cáseo }(6 / 10)\end{array}$ & $\begin{array}{l}\text { - Aerossaculite fibrinonecrótica difusa } \\
\text { moderada }(1 / 1)\end{array}$ & $-(1 / 1)$ \\
\hline Coração & $\begin{array}{l}\text { - Deposição de fibrina no } \\
\text { epicárdio }(2 / 10)\end{array}$ & $\begin{array}{l}\text { - Pericardite fibrinosa aguda difusa acentuada } \\
(2 / 10)\end{array}$ & NR \\
\hline
\end{tabular}

IHQ = imuno-histoquímica; intensidade de marcação: - = negativa; + = discreta; ++ = moderada; +++ = acentuada; $\mathrm{NR}$ = não realizado. 
sentados no Quadro 2. Macroscopicamente, foi observado na conjuntiva secreção serosa e edema com deposição de cáseo (7/10) (Fig.1); nos seios nasais secreção serosa com deposição de cáseo (4/10) (Fig.1); nos sacos aéreos espessamento, espuma e cáseo (6/10) (Fig.2A); na traqueia mucosa difusamente avermelhada (4/10); e nos pulmões pontos esbranquiçados de $0,5 \mathrm{~cm}$ de diâmetro (2/10). Além das lesões no sistema respiratório, foi observado, também, espessamento do saco pericárdico com deposição de fibrina (2/10) (Fig.2B). Em duas aves não foram observadas lesões macroscópicas.

No exame histopatológico, todos os casos de micoplasmose apresentaram lesões no sistema respiratório, sendo que em nove aves foram observadas lesões em mais de um órgão desse sistema. As lesões foram observadas em traqueia $(10 / 10)$, seios nasais $(5 / 5)$, conjuntiva $(3 / 4)$, sacos aéreos (1/1), pulmões (5/10) e coração (2/10). Na traqueia foi evidenciado espessamento da mucosa devido à hiperplasia do epitélio difusa acentuada com ausência de cílios, hiperplasia de glândulas mucosas e infiltrado linfoplasmocitário discreto (10/10) (Fig.3A). Em cinco aves foram observadas lesões pulmonares, caracterizadas por broncopneumonia fibrinonecrótica multifocal acentuada circundada por infiltrado de heterofilos, linfócitos, plasmócitos, macrófagos e células gigantes multinucleadas (5/10) com colônias bacterianas intralesionais (4/5) (Fig.3B). Nesses casos, ainda foi evidenciada hiperplasia do tecido linfoide peribronquial (BALT) moderada (2/5) a acentuada (1/5) formando nódulos linfoides subepiteliais (Fig.3C), hiperplasia epitelial da mucosa bronquial (3/5) e de glândulas mucosas (2/5). Nos seios nasais foi evidenciada hiperplasia do epitélio e das glândulas mucosas difusa acentuada associada a infiltrado inflamatório predominante de linfócitos e plasmócitos com formação de nódulos linfoides subepiteliais difuso acentuado (Fig.3D). Havia ainda moderada quantidade de muco e debris celulares no lúmen dos seios nasais (5/5). Na conjuntiva foi observada hiperplasia do epitélio difusa acentuada associada a infiltrado inflamatório predominante de linfócitos e plasmócitos com formação de nódulos linfoides subepiteliais difuso acentuado (Fig.3E) (3/4). Evidenciou-se, ainda, nos sacos aéreos, in- filtrado de heterófilos, macrófagos, linfócitos e plasmócitos associado à deposição de fibrina e debris celulares multifocal moderado (1/1). Em dois casos havia pericardite aguda caracterizada por exsudação de fibrina acompanhada por infiltrado de heterófilos, linfócitos, plasmócitos e macrófagos difuso acentuado (Fig.3F). Dos três casos em que foram realizadas culturas bacterianas, foram isolados Micrococcus sp., a partir de suabe dos seios nasais e dos pulmões (caso 1) e Escherichia coli, a partir de suabe de seios nasais (casos 7 e 8).

No exame de IHQ anti-MG pode ser detectada marcação na superfície extracelular dos cílios e/ou topo do epitélio da traqueia (10/10) (Fig.4A-B), dos cílios do epitélio bronquial dos pulmões (5/10) (Fig.4C) e no topo do epitélio e no exsudato luminal dos seios nasais (4/5) (Fig.4D). Não houve marcação na conjuntiva e nos sacos aéreos dos casos testados. Na IHQ anti-MS todas as amostras foram negativas. Através da IHQ foi observada ausência de reação cruzada entre as diferentes espécies de Mycoplasma. $\mathrm{O}$ controle positivo de $\mathrm{MG}$ apresentou resultado negativo para MS, o controle positivo de MS apresentou resultado negativo para MG e o controle positivo de $M$. hyopneumoniae apresentou resultado negativo com ambos os anticorpos.

Através da utilização de PCR em tempo real foi possível detectar a presença de MG em amostras de sete dos casos; não foi possível detectar a presença de MS em quaisquer das dez amostras (Quadro 1). As três aves onde não foi possível a detecção de MG correspondiam a amostras emblocadas em parafina, devido à indisponibilidade de material congelado.

Nos casos-controle foram observados à necropsia sacos aéreos abdominais opacos e com pequena deposição de espuma (3/10). No exame histopatológico havia aerossaculite heterofílica multifocal discreta (1/10), pneumonia granulomatosa focal discreta $(1 / 10)$ e pneumonia fibrino-heterofílica focal discreta (1/10). Em nenhum desses controles negativos houve marcação na IHQ para MG e MS. Nestes mesmos controles, foi identificado MG em três aves e MS em quatro aves, através de PCR em tempo real.
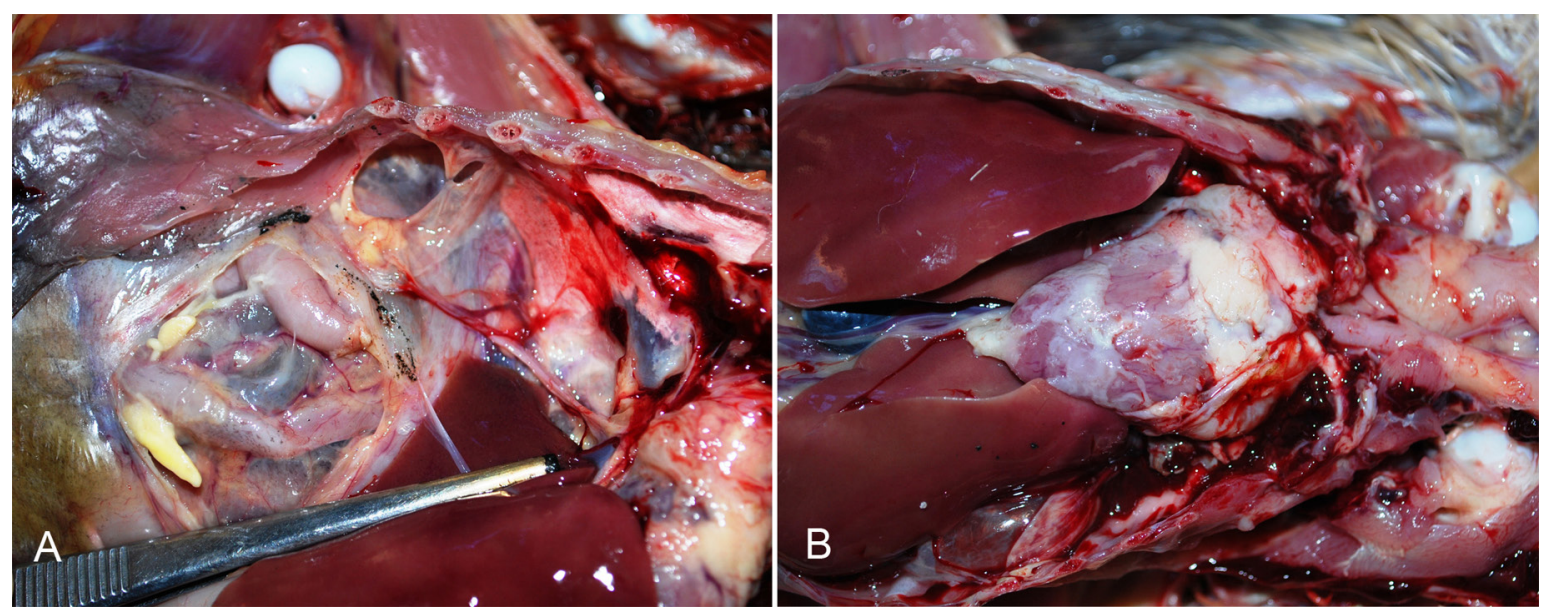

Fig.2. Infecção por Mycoplasma gallisepticum em galinhas. Lesões macroscópicas: (A) sacos aéreos espessados e com deposição de cáseo. (B) coração com deposição de fibrina sobre o epicárdio. 

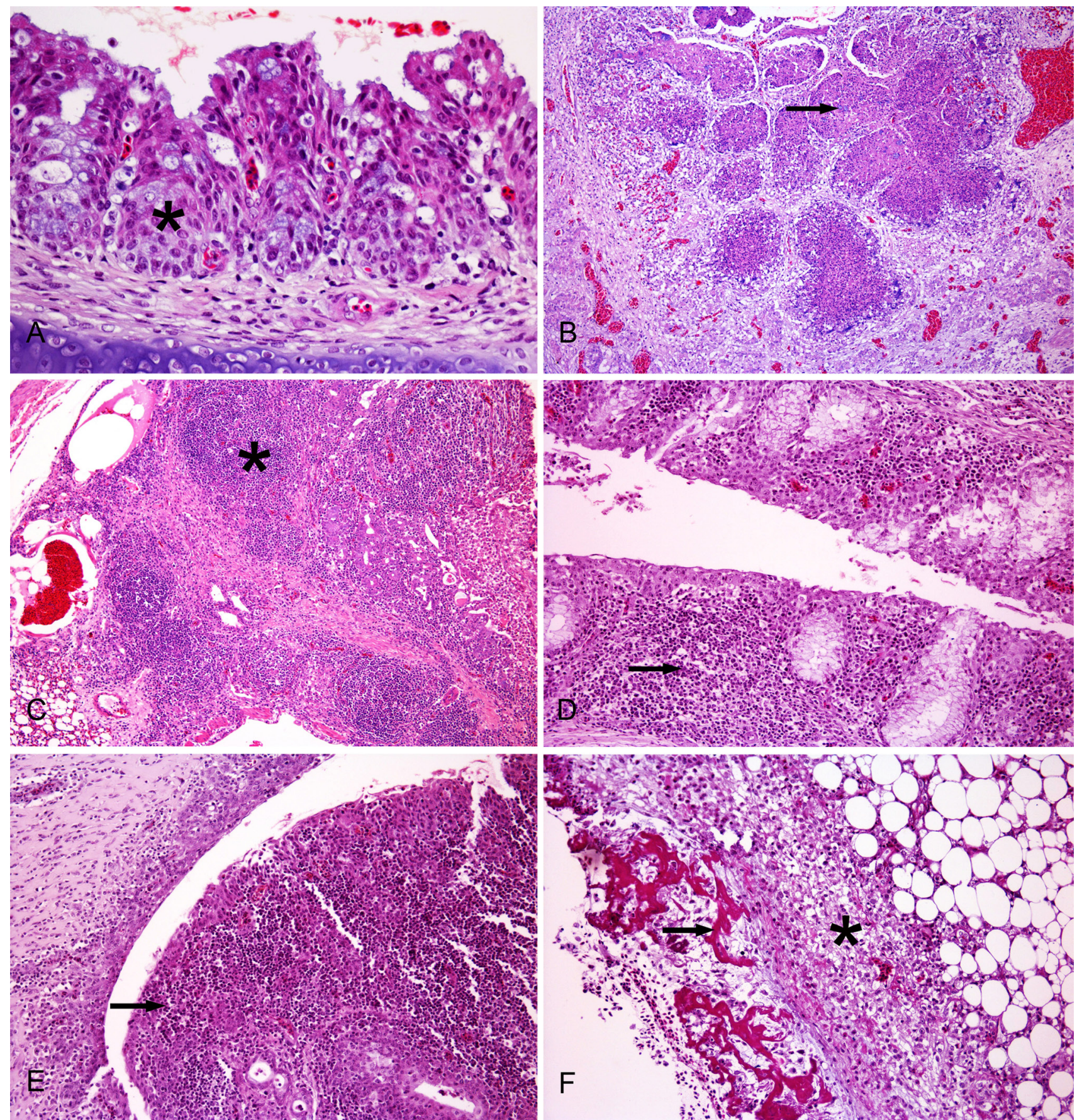

Fig.3. Infecção por Mycoplasma gallisepticum em galinhas. (A) Traqueia com hiperplasia do epitélio difusa acentuada e ausência de cílios (asterisco). HE, obj.40x. (B) Pulmões com broncopneumonia fibrinonecrótica e colônias bacterianas (seta) circundadas por células gigantes multinucleadas. HE, obj.10x. (C) Pulmões com hiperplasia do tecido linfoide peribronquial (BALT) acentuada (asterisco). HE, obj.10x. (D) Seios nasais com infiltrado linfoplasmocitário difuso moderado na mucosa (seta). HE, obj.20x. (E) Conjuntiva com infiltrado linfoplasmocitário difuso moderado (seta). HE, obj.20x. (F) Coração com pericardite aguda caracterizada por exsudação de fibrina (seta) acompanhada por infiltrado de heterófilos, linfócitos, plasmócitos e macrófagos (asterisco). HE, obj.20x.

\section{DISCUSSÃO}

No presente relato foram descritos dois surtos de infecção por Mycoplasma gallisepticum em galinhas de fundo de quintal utilizadas para a produção de ovos. Essa espécie de Mycoplasma é a mais patogênica e que tem a maior importância econômica para a produção avícola (Ley 2008). No Brasil, 250 surtos de micoplasmose por MG foram notifica- dos nos últimos 5 anos (2008-2012) (OIE 2013). Entretanto, é possível que o número de casos seja maior, pois muitos não são relatados.

A técnica de imuno-histoquímica anti-MG utilizada como método de diagnóstico apresentou boa concordância com os sinais clínicos, as lesões histopatológicas e os resultados da PCR em tempo real. Todos os casos que apresen- 


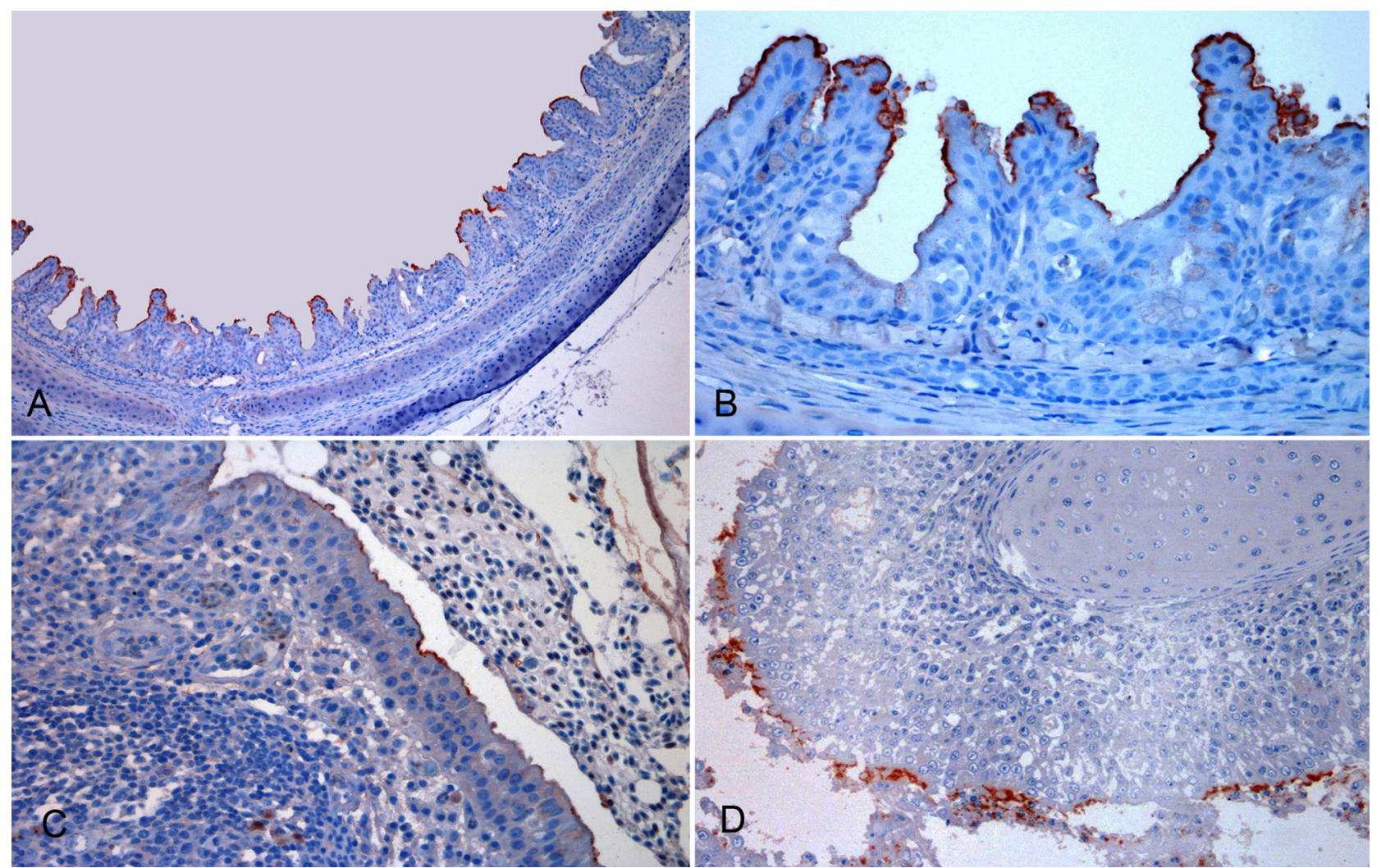

Fig.4. Imuno-histoquímica anti-Mycoplasma gallisepticum. (A) Traqueia com marcação nos cílios e/ou topo do epitélio. Obj.10x. (B) Maior aumento do A. Obj.40x. (C) Pulmões com marcação nos cílios do epitélio bronquial. Obj.40x. (D) Seios nasais com marcação no topo do epitélio e no exsudato luminal. Obj.40x. Estreptavidina-biotina ligada à peroxidase.

taram sinais clínicos respiratórios e lesões anatomopatológicas compatíveis com micoplasmose foram positivos na IHQ anti-MG e nenhum foi positivo para MS. Esse anticorpo demonstrou ser bastante específico, pois não houve reação cruzada com o anticorpo anti-MS e também para Mycoplasma de suíno (M. hyopneumoniae). Utilizando os mesmos anticorpos policlonais anti-MG e anti-MS do presente estudo, Yilmaz et al. (2011) encontraram seis animais simultaneamente positivos para MG e MS, no entanto os autores atribuíram a uma dupla infecção e não a uma reação cruzada. Anticorpos policlonais anti-MG e anti-MS podem exibir reações cruzadas entre si, pois essas duas espécies apresentam determinantes antigênicas em comum (Bradley et al. 1988, Radi et al. 2000).

Yilmaz et al. (2011) compararam IHQ, PCR e cultura bacteriana como método de diagnóstico de micoplasmose em frangos de corte e encontraram concordância de 96,3\% para MG e 95,7\% para MS entre essas três técnicas. Em mamíferos existem muitos estudos utilizando IHQ para detecção da infecção por micoplasma (Almeida et al. 2012), no entanto em aves o número de trabalhos é limitado (Nunoya et al. 1995, Nunoya et al. 1997, Radi et al. 2000, Yilmaz et al. 2011, Yilmaz \& Timurkaan 2011).

Nesse estudo foi observado que a imunomarcação anti-MG ocorreu principalmente na traqueia e nos seios nasais seguido pelos pulmões $(5 / 10)$. Não foi possível a avaliação dos sacos aéreos, pois foram colhidos de apenas uma ave. Em um estudo de MG em frangos de corte, a marcação também ocorreu principalmente em traqueia, pulmões e seios nasais (Yilmaz et al. 2011). Em infecção experimental por MG em perus a marcação foi significativamente mais intensa no epitélio dos seios nasais que no da traqueia e dos pulmões (Radi et al. 2000). Nos quatro casos em que se realizou IHQ de conjuntiva não foi observado marcação, no entanto, em um surto de ceratoconjuntivite em galinhas poedeiras a imunomarcação ocorreu no epitélio da conjuntiva e córnea (Nunoya et al. 1995).

Mycoplasma gallisepticum é uma bactéria extracelular e infecta a superfície do epitélio respiratório e da conjuntiva das aves (Nunoya et al. 1995, Ley 2008). Amostras patogênicas têm capacidade de adesão e invasão celular, podendo se disseminar para outros órgãos e tecidos levando a uma doença sistêmica (Ley 2008). Portanto, a marcação para MG na IHQ ocorreu na superfície extracelular do topo do epitélio traqueal, bronquial e sinusal, da mesma forma que foi evidenciada em outros estudos (Nunoya et al. 1995, Nunoya et al. 1997, Radi et al. 2000, Yilmaz et al. 2011, Yilmaz \& Timurkaan 2011). Esse tipo de marcação em superfície epitelial pode dificultar a interpretação do resultado, pois pode ser confundido com precipitação de cromógenos em bordos de tecidos e em desprendimento celular devido a artefatos de processamento. Portanto, essa foi a maior dificuldade encontrada na utilização dessa técnica, principalmente quando o tecido avaliado apresenta pouca imunomarcação.

A concordância da IHQ anti-MG e anti-MS e da PCR em tempo real para MG e MS de amostras de traqueia congeladas foi de $100 \%$. No entanto, em quatro casos só havia 
fragmentos de traqueia fixados em formalina e embebidos em parafina (FFEP) para a realização de PCR e desses, apenas um caso foi positivo para MG. A PCR para detecção de Mycoplasma pode ser realizada a partir de amostras de tecidos refrigerados ou congelados, ou ainda de tecidos FFEP. Entretanto, o processo de fixação em formalina pode inibir a amplificação de DNA. Em um estudo sobre diagnóstico de infecção por $M$. hyopneumoniae em suínos, associando o exame histopatológico, IHQ e PCR, observou-se que a positividade da PCR de tecidos FFEP diminuiu em comparação com as mesmas amostras refrigeradas ou congeladas (Almeida et al. 2012).

Com intuito de avaliar a especificidade do anticorpo, foram incluídas nesse estudo 10 aves que não apresentavam quadro clínico e/ou lesões compatíveis com micoplasmose e, em todos os casos a IHQ anti-MG e anti-MS foram negativas. Desses casos, a detecção por PCR em tempo real foi possível em três deles para MG e em quatro para MS. Devido a ausência de sinais clínicos e/ou lesões características é sugerido que essas aves fossem apenas portadoras. Apesar da alta sensibilidade e especificidade da técnica de PCR na detecção de micoplasmas, a mesma não permite diferenciar aves portadoras daquelas doentes (Jarquin et al. 2009).

O quadro clínico-patológico observado nesses dois surtos foi semelhante a outros relatos de infecção experimental e espontânea por MG em galiformes (Cookson \& Shivaprasad 1994, Nunoya et al. 1995, Radi et al. 2000, Ley 2008, Vitula et al. 2011, Yilmaz et al. 2011). A lesão causada por MG ocorre especialmente nos seios nasais, traqueia e sacos aéreos, embora os pulmões também possam estar envolvidos (Fletcher et al. 2008). Hiperplasia do epitélio respiratório associado à inflamação linfocitária com formação de agregados linfoides, principalmente hiperplasia de BALT são sugestivos de infecção por MG (Cookson \& Shivaprasad 1994, Nunoya et al. 1995, Radi et al. 2000, Fletcher et al. 2008, Ley 2008, Vitula et al. 2011, Yilmaz et al. 2011).

No presente relato foram observadas infecções bacterianas secundárias à micoplasmose. Os agentes associados foram E. coli e Micrococcus sp isolados de seios nasais e pulmões. Bactérias como E. coli, Pasteurella gallinarum, Pasteurella sp., Pseudomonas aeruginosa, Staphylococcus xylosus (Gross 1961, Fabricant \& Levine 1962, Gross 1990, Cookson \& Shivaprasad 1994, Vitula et al. 2011), bem como o vírus da bronquite infecciosa e da doença de Newcastle (Gross 1961, Fabricant \& Levine 1962, Gross 1990) já foram isoladas em infecções respiratórias sinérgicas com MG, levando a um agravamento do quadro clínico e da mortalidade. No epitélio respiratório, MG causa cilioestase, destruição e esfoliação das células epiteliais ciliadas e não-ciliadas propiciando infecções secundárias. Agentes imunossupressores, estressantes ou condições ambientais desfavoráveis, muitas vezes, são responsáveis por infecções respiratórias graves por MG (Ley 2008).

É possível que, nos dois surtos relatados no presente trabalho, a aquisição de novas aves pouco tempo antes do início dos sinais clínicos tenha sido a fonte de transmissão de MG. Essa bactéria pode ser transmitida de forma vertical e horizontal, direta ou indiretamente. Aves com infecções subclínicas podem ser importantes transmissores desse agente. 0 transporte e a mudança de ambiente, bem como outros fatores estressantes devido ao novo ambiente, também causam estresse e imunossupressão, favorecendo assim a exacerbação dos sinais clínicos e maior eliminação do agente no meio ambiente. A porta de entrada, geralmente, é o sistema respiratório superior ou a conjuntiva (Ley 2008).

A infecção por MG é uma importante causa de doença respiratória em aves de subsistência. A aplicação associada das técnicas de IHQ e de PCR em tempo real para a identificação de infecção e presença de M. gallisepticum, respectivamente, pode ser ferramenta importante no diagnóstico de micoplasmoses em aves, ainda mais quando associadas aos sinais clínicos e as lesões anatomopatológicas.

Agradecimentos.- Ao Dr. Roger Ayling do Animal Health and Veterinary Laboratories Agency, Mycoplasma Group, Department of Bacteriology, Addlestone, England por ceder gentilmente os anticorpos anti-MG e anti-MS para a realização da IHQ. À Dra. Naola Ferguson-Noel e a Dra. Monique Silva de França do Poultry Diagnostic \& Research Center, The Universy of Georgia, USA por cederem gentilmente os controles positivos de MS para a IHQ. Ao Leandro S. Machado do Departamento de Saúde Coletiva Veterinária e Saúde Pública, Faculdade de Veterinária, Universidade Federal Fluminense e as empresas Merial e Biovet por disponibilizarem os controles positivos de MG e MS para a PCR. À Coordenação de Aperfeiçoamento de Pessoal e Nível Superior (CAPES), Conselho Nacional de Desenvolvimento Científico e Tecnológico (CNPq) e à Fundação de Apoio à Pesquisa do Estado do Rio Grande do Sul (FAPERGS) pelo apoio financeiro.

\section{REFERÊNCIAS}

Almeida P.R., Andrade C.P., Almeida L.L., Oliveira L.G.S., Castro L.A., Zlotowski P., Silva S.C. \& Driemeier D. 2012. Nested-PCR for the detection of Mycoplasma hyopneumoniae in bronchial alveolar swabs, frozen tissues and formalin-fixed paraffin-embedded swine lung samples: comparative evaluation with immunohistochemical findings and histological features. Pesq. Vet. Bras. 32(8):715-720.

Bradley L.D., Snyder D.B. \& Van Deusen R.A. 1988. Identification of species-specific and inter-species-specific polypeptides of Mycoplasma gallisepticum and Mycoplasma synoviae. Am. J. Vet. Res. 49:511-515.

Brasil. Ministério da Agricultura, Pecuária e Abastecimento (MAPA). Instrução normativa no 44 de 23 de agosto de 2001. Aprova as normas técnicas para o controle e a certificação de núcleos e estabelecimentos avícolas para a Micoplasmose Aviária (Mycoplasma gallisepticum, synoviae e melleagridis). Diário Oficial da União. Brasília, DF, p.68-70, de 24 de agosto de 2001, Seção I.

Buim M.R., Mettifogo E., Timenetsky J., Kleven S. \& Ferreira A.J.P. 2009. Epidemiological survey on Mycoplasma gallisepticum and M. synoviae by multiplex PCR in commercial poultry. Pesq. Vet. Bras. 29:552-556.

Callison S.A., Riblet S.M., Sun S., Ikuta N., Hilt D., Leiting V., Kleven S.H., Suarez D.L. \& García M. 2006. Development and validation of a Real-Time Taqman polymerase chain reaction assay for the detection of Mycoplasma gallisepticum in naturally infected birds. Avian Dis. 50:537-544.

Cookson K.C. \& Shivaprasad H.L. 1994. Mycoplasma gallisepticum infection in chukar partridges, pheasants, and peafowl. Avian Dis. 38:914-921.

Fabricant J. \& Levine P.P. 1962. Experimental production of complicated chronic respiratory disease infection ("air sac" disease). Avian Dis. 6:1323.

Fletcher O.J., Abdul-Aziz T. \& Barnes H.J. 2008. Respiratory system, p.128163. In: Fletcher O.J. (Ed.), Avian histopathology. Omni press, Madison.

Gomes A.M., Costa L.L., Vilela D.A.R., Marques M.V.R., Carvalhaes A.G., Marin S.Y., Costa M.P., Horta R.S., Resende J.S., Martins N.R.S. 2010. Detection of Mycoplasma gallisepticum in dead captive psittacines in Belo Horizonte, Brazil. Rev. Bras. Cienc. Avic. 12:75-78.

Gross W.B. 1961. The development of "air sac disease". Avian Dis. 5:431439. 
Gross W.B. 1990. Factors affecting the development of respiratory disease complex in chickens. Avian Dis. 34:607-610.

Jarquin R., Schultz J., Hanning I. \& Ricke S.C. 2009. Development of a Real-Time polymerase chain reaction assay for the simultaneous detection of Mycoplasma gallisepticum and Mycoplasma synoviae under industry conditions. Avian Dis. 53:103-107.

Kleven S.H. 1975. Antibody response to avian mycoplasmas. A. J. Vet. Res. 36:563-565.

Kleven S.H. 2008. Mycoplasmosis, p.805-807. In: Saif Y.M. (Ed.), Diseases of Poultry. $12^{\text {th }}$ ed. Blackwell, Iowa.

Kleven S.H. \& Ferguson-Noel N. 2008. Mycoplasma synoviae infection, p.845-856. In: Saif Y.M. (Ed.), Diseases of Poultry. $12^{\text {th }}$ ed. Blackwell, Iowa.

Ley D.H. 2008. Mycoplasma gallisepticum infection, p.807-834. In: Saif Y.M. (Ed.), Diseases of Poultry. $12^{\text {th }}$ ed. Blackwell, Iowa.

Machado L.S., Nascimento E.R., Pereira V.L.A., Almeira D.O., Silva R.C.F. \& Santos L.M.M. 2012. Mycoplasma gallisepticum como fator de risco no peso de lotes de frangos de corte com condenação por aerossaculite na Inspeção Sanitária Federal. Pesq. Vet. Bras. 32:645-648.

Minharro S., Linhares G.F.C., Andrade M.A., Rocha P.T. \& Santana A.P. 2001. Envolvimento de Escherichia coli, de Mycoplasma gallisepticum e de Mycoplasma synoviae em lesões de sacos aéreos em frangos abatidos no Estado de Goiás. Ci. Anim. Bras. 2:111-117.

Nunoya T., Yagihashi T., Tajima M. \& Nagasawa Y. 1995. Occurrence of keratoconjunctivitis apparently caused by Mycoplasma gallisepticum in layer chickens. Vet. Pathol. 32:11-18.
Nunoya T., Kanai K., Yagihashi T., Hoshi S., Shibuya K. \& Tajima M. 1997. Natural case of salpingitis apparently caused by Mycoplasma gallisepticum in chickens. Avian Pathol. 26:391-398.

OIE. World Organization for Animal Health. Mycoplasmosis (M. gallisepticum). Paris, [20--?]. Disponível em: <http://www.oie.int/wahis_2/ public/wahid.php/Diseaseinformation/statusdetail>. Acesso em: 12 outubro. 2013.

Radi Z.A., Trampel D.W., Smith B.S., Rosenbusch R.F. \& Goll F. 2000. Immunohistochemical detection of Mycoplasma gallisepticum antigens in turkey respiratory tissues. Avian Dis. 44:399-407.

Raviv Z. \& Kleven S. 2009. The development of diagnostic Real-Time Taqman PCRs for the four pathogenic Avian Mycoplasmas. Avian Dis. 53:103-107.

Vitula F., Peckova L., Bandouchova H., Pohanka M., Novotny L., Jira D., Kral J., Ondracek K., Osickova J., Zendulkova D., Rosenbergova K., Treml F. \& Pikula J. 2011. Mycoplasma gallisepticum infection in the grey partridge Perdix perdix: outbreak description, histopathology, biochemistry and antioxidant parameters. Vet. Res. 7:34.

Yilmaz F., Timurkaan N., Kiliç A., Kalender H. \& Kilinç Ü. 2011. Detection of Mycoplasma synoviae and Mycoplasma gallisepticum in chicken by immunohistochemical, PCR and culture methods. Revue Méd. Vét. 162(2):79-86.

Yilmaz F. \& Timurkaan N. 2011. Detection of Mycoplasma gallisepticum and Mycoplasma synoviae antigens by immunohistochemical method in pneumonic broiler chicken lungs. J. Anim. Vet. Adv. 10(19):25572560 . 